www.jmscr.igmpublication.org

Impact Factor 3.79

Index Copernicus Value: 5.88

ISSN (e)-2347-176x ISSN (p) 2455-0450

crossref DOI:_http://dx.doi.org/10.18535/jmscr/v4i1.26

Journal Of Medical Science And Clinical Research

\title{
Cytogenetic Study in Couples with Primary Infertility
}

Authors

\author{
Dr Rakhi More ${ }^{1}$, Dr Shabana Borate ${ }^{2}$, Dr S.D.Gangane ${ }^{3}$ \\ ${ }^{1}$ Associate Professor, Department of Anatomy, K.J.Somaya Medical College \& Research Centre, Somaiya \\ Ayur Vihar, Everard nagar, , Sion, Mumbai 22, India. \\ Email:dr_rakhimmore@rediffmail.com \\ ${ }^{2}$ Associate Professor, Genetics Division, Department of Anatomy, Grant Government Medical College and \\ Sir J.J. Group of hospitals, Byculla, Mumbai 8,India \\ Email:drshabaana@gmail.com \\ ${ }^{3}$ Professor and Head, Department of Anatomy, Terna Medical College, Nerul, Navi Mumbai, India \\ Email: gangane@gmail.com \\ Corresponding Author
}

\section{Dr Rakhi More}

Associate Professor, Dept of Anatomy, K.J.Somaya Medical College \& Research Centre, Sion, Mumbai.

Email-dr_rakhimmore@rediffmail.com

\begin{abstract}
Fertility denotes the ability of a man and woman to reproduce. Conversely, infertility denotes lack of fertility, an involuntary reduction in the ability to produce children. A total of thirty three couples were studied in an attempt to find out the cytogenetic causes in primary infertility. The couples were assessed for other contributory factors like age, consanguinity, anatomical abnormalities, hormonal causes or any other medical causes. Cytogenetic analysis of the infertile couples revealed that chromosomal abnormalities were present in one of the partner in $36.36 \%$ of couples. Chromosomal abnormalities were found in $24.24 \%$ females and $12.12 \%$ males. Among the chromosomal abnormalities, numerical abnormalities were present in $18.18 \%$ couples and structural abnormalities were present in $12.12 \%$ couples. Most common among the numerical abnormalities was 47, XXY i.e 3 cases, mosaicism was seen in 3 cases ( 2 females and 1 male). 46, XY karyotype was found in two phenotypic females with primary infertility. Structural abnormalities were present in $12.12 \%$ of female patients.

Keywords- Primary infertility, chromosomal aberrations, karyotyping, numerical abnormalities, structural abnormalities.
\end{abstract}

\section{Introduction}

Infertility is seldom, if ever, a physically debilitating disease. It may however, severely affect the couple's psychological harmony, sexual life and social function ${ }^{[1]}$ In some cultures childlessness may cast a heavy shadow on the psychological and social adequacy of the female and diminish the social standing of the male partner. Most cultures regard children as an extension of self as bearers and perpetuators of the family name and tradition as well as an expansion of one's hopes, aims and strivings.

Infertility may be further classified as primary infertility, in which no previous pregnancies have 
occurred, and secondary infertility, in which a prior pregnancy, although not necessarily a live birth, has occurred $^{[2]}$. The definition proposed by WHO states that 'Infertility can be primary, if the couple has never conceived despite cohabitation and exposure to pregnancy (without contraception) for a period of two years ${ }^{[3]}$. 60-80 million couples experience infertility worldwide ${ }^{[4]}$. The important role of genetic factors in pathogenesis of infertility is now increasingly recognized ${ }^{[5]}$. Chromosome aberrations may cause infertility in both men and women $^{[6,7]}$ The main cause of female infertility is amenorrhoea not due to pregnancy, lactation or menopause is around 3-4 \% ${ }^{[8,9]}$. The contribution of male factors to infertility is $30-50 \%$. Environmental as well as genetic factors are involved in the decrease of the reproductive potential in male ${ }^{[10]}$. The main genetic factors involved in male infertility are chromosomal abnormalities and Ychromosomal microdeletions within the Yq11 region ${ }^{[11]}$.

\section{Material and Methods}

The study was conducted over a period of 21 months, thirty three couples with history of primary infertility referred to the Genetic Division of Anatomy Department Grant Medical College Mumbai were selected for this study. The patients were referred from this Institute itself, other Government Hospitals, and Municipal \& Private Hospitals in and around Mumbai.

All couples having a history of primary infertility attending the genetic clinic were initially screened with a detailed gynaecological and clinical history. All these patients were screened for chromosomal abnormalities, after due consent. Patients were evaluated for detailed family history and occupational history. Clinical examination of the patients, ultrasonography, Barr body examination of patient was done wherever necessary. Cytogenetic analysis was carried out in all these couples.

Karyotyping:-

1-2 $\mathrm{ml}$ of peripheral blood of the patient was collected in sterilized, heparinized $5 \mathrm{ml}$ syringe by venipuncture. Planting of the culture was done on the same day. The contents of each culture vial were mixed gently and incubated for 3 days at $37^{\circ} \mathrm{C}$. For each patient two vials were planted with PHA-M. The planted cultures were shaked well after every 24 hours. This enhances better growth. Harvesting of the culture was done using colchicines (Gibco BRL). After harvesting, Giemsa banding was done. Metaphases were screened under microscope.

Observations and Results

Table no1- Gender wise comparison of age in years

\begin{tabular}{|c|c|c|c|c|c|c|}
\hline \multirow{3}{*}{$\begin{array}{l}\text { Age in } \\
\text { years }\end{array}$} & \multicolumn{4}{|c|}{ Primary infertility } & \multirow{2}{*}{\multicolumn{2}{|c|}{ Total }} \\
\hline & \multicolumn{2}{|c|}{ Male } & \multicolumn{2}{|c|}{ Female } & & \\
\hline & No & $\%$ & No & $\%$ & No & $\%$ \\
\hline$<=20$ & 0 & 0.00 & 4 & 12.12 & 4 & 6.06 \\
\hline 21 to 25 & 6 & 18.18 & 15 & 45.45 & 21 & 31.82 \\
\hline 26 to 30 & 14 & 42.42 & 11 & 33.33 & 25 & 37.88 \\
\hline 31 to 35 & 10 & 30.30 & 3 & 9.09 & 13 & 19.70 \\
\hline 36 to 40 & 2 & 6.06 & 0 & 0.00 & 2 & 3.03 \\
\hline$>=40$ & 1 & 3.03 & 0 & 0.00 & 1 & 1.52 \\
\hline Total & 33 & 100 & 33 & 100 & 66 & 100 \\
\hline
\end{tabular}

Table no 2- Other associated parameters studied

\begin{tabular}{|l|l|l|l|}
\hline Sr No & Parameter studied & $\begin{array}{l}\text { No of } \\
\text { patients }\end{array}$ & $\%$ \\
\hline 1 & $\begin{array}{l}\text { Anatomical Abnormalities } \\
\text { in both sexes }\end{array}$ & 17 & 25.76 \\
\hline 2 & $\begin{array}{l}\text { Hormonal imbalance in } \\
\text { females }\end{array}$ & 4 & 12.12 \\
\hline 3 & $\begin{array}{l}\text { Hormonal imbalance in } \\
\text { males }\end{array}$ & 2 & 6.06 \\
\hline 4 & $\begin{array}{l}\text { Associated medical } \\
\text { illness in both sexes }\end{array}$ & 5 & 7.58 \\
\hline 5 & $\begin{array}{l}\text { Menstrual Disorders in } \\
\text { females }\end{array}$ & 9 & 27.27 \\
\hline 6 & $\begin{array}{l}\text { Oligospermia and } \\
\text { Azoospermia in males }\end{array}$ & 9 & 27.27 \\
\hline 7 & Consanguinity in couples & 3 & 9.09 \\
\hline
\end{tabular}

Table 3 - Frequency of chromosomal abnormalities in study population

\begin{tabular}{|l|l|l|l|l|}
\hline $\begin{array}{l}\text { Chromosomal } \\
\text { abnormality }\end{array}$ & \multicolumn{2}{|l|}{ (Male) } & \multicolumn{2}{l|}{ (Female) } \\
\hline & $\mathrm{n}$ & $\%$ & $\mathrm{n}$ & $\%$ \\
\hline Numerical & 04 & 12.12 & 02 & 6.06 \\
\hline Structural & 00 & 00 & 04 & 12.12 \\
\hline Sex reversal & 00 & 00 & 02 & 6.06 \\
\hline
\end{tabular}


Table 4- Karyotype of study population with Structural Chromosomal abnormalities

\begin{tabular}{|l|l|}
\hline Sr No & $\begin{array}{l}\text { Karyotype } \\
\text { (Females) }\end{array}$ \\
\hline 1 & $45, \mathrm{XX},-13 \mathrm{t}(13 \mathrm{q} / 14 \mathrm{q})$ \\
\hline 2 & $46, \mathrm{X}, \mathrm{i}(\mathrm{Xq})$ \\
\hline 3 & $46, \mathrm{XX}, 15 \mathrm{p}+$ \\
\hline 4 & $46, \mathrm{XX}, 15 \mathrm{~s}+$ \\
\hline
\end{tabular}

Table 5- Karyotype of study population with Numerical Chromosomal abnormalities

\begin{tabular}{|l|l|l|}
\hline Sr No & $\begin{array}{l}\text { Karyotype } \\
\text { (Females) }\end{array}$ & $\begin{array}{l}\text { Sex of } \\
\text { patients }\end{array}$ \\
\hline 1 & $\begin{array}{l}46, \mathrm{XX} / 45 \mathrm{X} \\
90 \% \quad 10 \%\end{array}$ & Female \\
\hline 2 & $\begin{array}{l}46, \mathrm{XX} / 45 \mathrm{X} \\
50 \% \quad 50 \%\end{array}$ & Female \\
\hline 3 & $\begin{array}{l}46, \mathrm{XY} / 47, \mathrm{XXY} \\
40 \% \quad 60 \%\end{array}$ & Male \\
\hline 4 & $47, \mathrm{XXY}$ & Male \\
\hline 5 & $47, \mathrm{XXY}$ & Male \\
\hline 6 & $47, \mathrm{XXY}$ & Male \\
\hline
\end{tabular}

\section{Discussion}

Infertility ranks high among the causes of deep unhappiness in marriage. The inability to procreate is thus always perceived as a denial of basic rights, san injustice and a disappointment, sometimes bordering on grief.

Age impacts on fertility; aging of the reproductive system plays an important role in it. In our present study we found that out of the 33 women referred for primary infertility $15(45.45 \%)$ were in the age group 21-25.A paternal age greater than 40 is associated with a $20 \%$ greater chance of birth defects in the offspring ${ }^{[12]}$. The male patients referred for primary infertility was maximum in the age group 26-30 i.e 14 (42.42\%).

Consanguineous marriages have an above-average risk of producing offspring homozygous for some deleterious recessive gene ${ }^{[13]}$. In the present study, 3 couples i.e $9.09 \%$ had a history of consanguinity. Disorders of ovulation account for about $30 \%$ to $40 \%$ of all cases of female infertility ${ }^{[2]}$. Out of the 33 females studied 9 patients, $(27.27 \%)$ with primary infertility showed menstrual disorders. Of these 9 patients 2 had primary amenorrhoea, and chromosome constituent of both these patients was 46, XY.

Spontaneous pregnancy losses occurring before 10 weeks of gestation may result from a number of alterations in normal progesterone production or use $^{[2]}$. In our present study 4 out of $33(12.12 \%)$ women with primary infertility had hormonal problems In males 2 out of $33(6.06 \%)$ males with primary infertility had hormonal problems.

Any severe systemic illness such as tuberculosis, diabetes mellitus, renal and liver failure, metastatic cancer etc can lead to disruption of hypothalamic pituitary- ovarian axis and cause infertility ${ }^{[2]}$ In present study, 5 patients i.e $7.58 \%$ had associated medical illness.

Several disorders of spermatogenesis lead to permanent and irreversible infertility. In the present study 9 male patients i.e $27.27 \%$ had oligospermia and azoospermia.

\section{Chromosomal abnormalities}

The rate of Chromosomal aberrations in the general population is less than $1 \%$, while it is higher in patients with poor reproductive history. Worldwide, $2-7 \%$ of couples are infertile ${ }^{[14]}$.

In the present study of 33 couples, in none of the couple, both partners showed chromosomal abnormality. Chromosomal abnormalities were found in 12 couples i.e $36.36 \%$. Out of these abnormalities 6 i.e $18.18 \%$ were numerical abnormalities. Structural abnormalities were found in 4 couples i.e $12.12 \%$. Among the numerical abnormalities 2 were found in the females and 4 in males. Quilter et al ${ }^{[15]}$, suggested that routine cytogenetic analysis of infertile male patients is required. The numerical abnormalities in present study included mosaicism in (2 females and 1 male), 4 males with Klinefelter syndrome. Duzcan et $\mathrm{al}^{[14]}$ found mosaicism as a cause of infertility in $1.97 \%$ patients. Duzcan et al ${ }^{[14]}$ also reported $6.15 \%$ phenotypic females with XY karyotype.Two phenotypic females with a karyotype $46, \mathrm{XY}$ were found in the present study. Both these women had 
been referred for primary infertility. In the present study, structural abnormalities were found in 4 couples they were $45, X X,-13 t(13 q / 14 q), 46$, X,I (Xq), 46XX,15S $\mathrm{S}^{+}, 46, \mathrm{XX}, 15 \mathrm{p}^{+}$. Female: male ratio, reason for this ratio is explained by by Kjessler et al [16] , as in males chromosomal translocations may lead to spermatogenic arrest rendering them sterile. In the present study, the female to male ratio of chromosomal abnormality is $2: 1$.

\section{Conclusion}

Chromosomal disorders play a significant role in primary infertility. The identification of chromosomal aberrations facilitates the genetic counselling for further management and for providing options for assisted reproductive technology and finally for adoption.

\section{References}

1. Jeffcoate's - Principles of Gynecology, $5^{\text {th }}$ edition, pg 635-660,1986.

2. Novak's Gynaecology, $13^{\text {th }}$ edition pg 9731107.

3. WHO: Challenges in reproductive health research: Biennial report 1992-1993, Geneva, WHO(1994).

4. Rao A. Kamini, "The Infertility Manual" $2^{\text {nd }}$ edition, pg 42-53,126-131 and 528-535.

5. Gorduza EV, Stoica O, Covic M. The importance of genetic factors in pathogenesis of central infertility( hypothalamic and pituitary) Rev Med Chir Soc Med Nat 1si. 2003;107:28-34.[Pubmed]

6. Chandely AC. Chromosome anomalies and $\mathrm{Y}$ - chromosome microdeletions as casual factors in male infertility. Hum Reprod.1998;13(Suppl):45-50 .[Pubmed]

7. Azimi C, Khaleghian M, Farzanfar F. Cytogenetic studies among Iranian infertile men: The first long term report of $20 \mathrm{yr}$. Afr J Biothecnol. 2012; 11: 8973-8978.

8. Petterson F,Fries H, Nillus SJ.Epidemiology of secondry amenorrhoea. Incidence and prevalence rates.Am J Obstet Gynecol. 1973;117:80-86 [Pubmed].
9. Bachmann G, Kemmann E. Prevalance of oligomenorrhoea and amenorrhoea in a college population. Am J Obstet Gynecol. 1982;144:98-102 .[Pubmed]

10. Krausz C, Quintana -Murci L and Mc Elreavey K : Prognostic value of Y deletion analysis: what is the clinical prognostic value of $\mathrm{Y}$ chromosome microdeletion analysis? Hum Reprod. 15: 1431-1434.2000.

11. Vogt P, Chandley AC, Hargreave TB, Keil $\mathrm{R}$, Ma $\mathrm{K}$ and Sharkey A: Microdeletions in interval 6 of the $\mathrm{Y}$ chromosome of males with idiopathic sterility point to disruption of AZF, a human spermatogenesis gene. Hum Genet. 89: 491-496.1992.

12. Lian Z, Zack MM, Erickson JD: Paternal age and the occurrence of birth defects, Am J Hum Genet, 39: 648, 1986.

13. an Z, Zack MM, Erickson JD; Paternal age and the occurrence birth defects, Am J Hum Genet 39:648,1986.

14. Harper PS. Practical Genetic Counselling, $6^{\text {th }}$ Ed. London: Arnold. 2004: 70-72.

15. Duzcan F, Atmaca M, Cetin G and Bagci H, Cytogenetic studies in patients with reproductive failure, Acta Obstet Gynecol Scand, 82;53-56,2003.

16. Quilter CR, Svennevik EC, Serhal P, Cytogenetic and $\mathrm{Y}$ chromosome microdeletion screening of a random group of infertile males. Fertility and Sterility, vol 79, 2: 301-307,2003.

17. Kjessler B, Chromosomal constitution and male reproductive failure.In Mancini RE, Martini (eds). Male Fertility and Sterility Academic Press, New York, pg 231-47. 